\title{
Greater occipital nerve block in management of chronic migraine; exploring clinical effectiveness and patient experience
}

\author{
JC Williamson", J Winston*, R De Silva \\ From The European Headache and Migraine Trust International Congress \\ London, UK. 20-23 September 2012
}

Greater Occipital Nerve (GON) Block is a recognized treatment modality in the management of chronic migraine. Our study aimed to assess the patient experience and clinical effect of this procedure in 20 patients undergoing this intervention. 20 patients with a diagnosis of chronic migraine were admitted from the outpatient department for GON block procedure. Patients were asked to complete a pre-procedure questionnaire. This questionnaire focused on four domains: 1. Duration of symptoms, 2. Pre procedure 'Headache Impact Test' (HIT-6) score, 3. An objective pain score of current pain at time of procedure, 4 . Subjective description of current pain character at the time of procedure. 20 minutes following the procedure patients were asked to repeat the objective and subjective assessment of current pain. At a one-month interval patients completed a repeat HIT-6 score.

\section{Summary of key findings}

Only $40 \%$ of patients reported a reduction in pain score 20 minutes post procedure. 2. A majority of patients (85\%) reported a change in the subjective nature of the pain 20 minutes post procedure 3 . A majority of patients $(80 \%)$ scored a lower HIT-6 score one month following procedure then prior to procedure. Average score difference was 5. 4. There was no clear correlation between symptom duration and reported improvement in immediate and one month assessment of headache. We hope to present full details of patient demographics, breakdown of pre and post procedure HIT-6 scores as well as patient feedback of their experience of undergoing a GON block procedure.
Published: 21 February 2013

\section{doi:10.1186/1129-2377-14-S1-P65}

Cite this article as: Williamson et al:: Greater occipital nerve block in management of chronic migraine; exploring clinical effectiveness and patient experience. The Journal of Headache and Pain 2013 14(Suppl 1): P65.
Submit your manuscript to a SpringerOpen ${ }^{\circ}$ journal and benefit from:

- Convenient online submission

- Rigorous peer review

Immediate publication on acceptance

- Open access: articles freely available online

- High visibility within the field

- Retaining the copyright to your article

Submit your next manuscript at $\boldsymbol{~ s p r i n g e r o p e n . c o m ~}$ 